\title{
POLITYCZNO-EKONOMICZNE IMPLIKACJE EPIDEMII KORONAWIRUSA DLA FEDERACJI ROSYJSKIEJ
}

\section{The Political and Economic Implications of the Coronavirus Pandemic for the Russian Federation}

The main purpose of this article is to analyse the political and economic implications of the coronavirus pandemic for the Russian Federation. I intend to take a closer look at the views of Polish and foreign scientists on the subject matter, focusing particularly on the possible increase in the significance of Russia in the international arena and the economic problems of this country that may occur in the near future.

At the beginning, I refer to the political consequences of the pandemic for Russia, focusing on the first cases of infections in this country and the attempt of the Kremlin authorities to divert attention from their internal problems by spreading theories, according to which the United States is primarily responsible for the spread of this disease. Further on, I touch upon the problem of a possible extension of Vladimir Putin's rule and try to outline the reasons why the Russian leader has decided to take this step. Moreover, I describe the implications of the pandemic for Russia's foreign policy, especially in relations to the United States, Western Europe, China, the Middle East and the post-Soviet countries: Belarus and Ukraine. I also present the impact of the pandemic conditions on the Russian economy and health care.

In conclusion, I try to answer the question of whether the pandemic will cause significant changes in the internal policy of the Russian Federation. I also try to determine whether Putin's power may contribute to strengthening Russia's position on the international arena in the coming years. 


\section{WPROWADZENIE}

Pandemia koronawirusa (SARS COV-2), zapoczątkowana na przełomie 2019 i 2020 roku, w chińskim mieście Wuhan, spowodowała w krótkim czasie znaczące zmiany zarówno na płaszczyźnie politycznej, jak i ekonomicznej w różnych rejonach świata. Jednym $z$ państw dotkniętych tym problemem jest Rosja, w której od grudnia 1999 roku niepodzielna władzę sprawuje prezydent Władimir Putin. W tekście tym postaram się scharakteryzować obecna sytuację w Federacji Rosyjskiej w dobie walki $\mathrm{z}$ chorobą oraz przedstawić polityczno-ekonomiczne jej konsekwencje. Celem moich rozważań będzie ponadto próba dokonania oceny, czy powinniśmy spodziewać się zmian w rosyjskiej polityce zagranicznej, wymuszonych zjawiskiem pandemii, wobec najważniejszych dla Rosji podmiotów - Stanów Zjednoczonych, Europy Zachodniej, Chin, Bliskiego Wschodu oraz obszaru postradzieckiego. Przedmiotem mojego zainteresowania będzie siła rzeczy także sytuacja ekonomiczna Rosji i perspektywy na nadchodząca przyszłość w tej materii. W powyższym kontekście należy postawić kilka pytań badawczych - kiedy i jak Rosja zareagowała na pierwsze przypadki zakażeń w Chinach oraz na swoim terytorium? Czy epidemia przyczyniła się do podjęcia przez Putina decyzji w sprawie zresetowania jego dotychczasowych kadencji sprawowanej władzy? Jakie kroki poczyniła do tej pory Rosja na rzecz powstrzymania pandemii? Jak moga przedstawiać się w przyszłości relacje Rosji z USA, Europa Zachodnią, Chinami, Bliskim Wschodem oraz krajami obszaru postsowieckiego? W jakim stopniu i w jakich obszarach koronawirus doprowadził do pogorszenia się stanu rosyjskiej gospodarki? I wreszcie, jakie perspektywy czekaja rosyjską ekonomię?

\section{POLITYCZNE IMPLIKACJE EPIDEMII KORONAWIRUSA W ROSJI}

Pandemia koronawirusa na świecie przypadła w bardzo niekorzystnym momencie dla Rosji. W obliczu pewnego uspokojenia sytuacji w Syrii oraz na Ukrainie społeczeństwo rosyjskie na przełomie 2019 i 2020 roku zaczęło zwracać coraz większą uwagę na pogłębiajace się trudności ekonomiczne kraju. Mimo nasilającej się w rosyjskich środkach masowego przekazu presji na Białoruś oraz podjęcia ponownej kampanii oskarżycielskiej przeciwko Polsce sugerującej jej współ- 
udział w wybuchu II wojny światowej, w mediach społecznościowych częściej zaczęły się pojawiać informacje o problemach gospodarczych kraju i skorumpowaniu elity władzy, w tym premiera Dmitrija Miedwiediewa. W obliczu spadającego poparcia społecznego oraz w celu poprawy wizerunku Putin zdecydował się w styczniu 2020 roku odsunać byłego prezydenta Rosji od zajmowanego stanowiska i mianował na premiera Michaiła Miszustina, który miał za zadanie zainicjować nowy program socjalny dla najbiedniejszych Rosjan ${ }^{1}$. Ruch ten miał także przywrócić wizerunek Putina jako osoby, która dba o poziom życia przeciętnego Rosjanina. Zmiana szefa rządu nie przysporzyła jednak prezydentowi zwiększenia zaufania, które w styczniu wynosiło jedynie 35 proc. $^{2}$ Pierwsze informacje o zagrożeniu epidemicznym pochodzacym $z$ Chin nie spotkały się $z$ właściwa reakcją władz rosyjskich. Początkowe przypadki zachorowań z 31 stycznia 2020 roku dotyczyły dwóch Chińczyków zamieszkujących Syberię. Po ponad trzech tygodniach bez nowych zgłoszonych infekcji koronawirus COVID-19 został potwierdzony u kilku obywateli rosyjskich wracających z zagranicy, w szczególności $z$ Włoch ${ }^{3}$. Jeden $z$ ponownych przypadków stwierdzono 4 marca $^{4}$. Wraz ze wzrostem zachorowań władze podejmowały coraz ostrzejsze kroki dotyczące wprowadzenia zakazu wjazdu do Rosji dla mieszkańców niektórych państw ościennych, m.in. Iranu czy Białorusi. Ostatecznie 18 marca zamknięto możliwość wjazdu do Rosji dla wszystkich obcokrajowców ${ }^{5}$. Praktycznie jednak do tego momentu władze na Kremlu wyrażały wręcz pogląd, że choroba ta nie dotyczy obszaru Rosji. Należy zaznaczyć, że w pierwszej fazie epidemii, tj. od stycznia 2020 roku, Moskwa dążyła do przedstawienia koronawirusa jako zjawiska powstałego w amerykańskim laboratorium, mającego na celu zaszkodzić międzynarodowej pozycji Rosji oraz Chin. Jak słusznie wskazuje Andrzej Szabaciuk, rosyjska kampania

\footnotetext{
1 A. Legucka, Rosja wobec pandemii COVID-19, https://www.pism.pl/publikacje/Rosja_wobec_pandemii_COVID19 [dostęp: 13 czerwca 2020].

2 „Styczniowa rewolucja” nie pomogka. Putinowi ufa coraz mniej Rosjan, https://warsawinstitute.org/pl/styczniowa-rewolucja-nie-pomogla-putinowi-ufa-coraz-mniej-rosjan/ [dostęp: 27 września 2020].

3 M. Russell, Russia and the coronavirus crisis, https://www.europarl.europa. eu/RegData/etudes/ATAG/2020/649389/EPRS_ATA(2020)649389_EN.pdf, s. 1 [dostęp: 18 czerwca 2020].

4 Отчёт о текущей ситуаиии по борьбе с коронавирусом, https://xn--80aesfpebagmfblc0a.xn--p1ai/ai/doc/72/attach/2020-03-25_coronavirus_government_report.pdf, s. 8 [dostęp: 17 czerwca 2020].

5 Koronawirus $w$ Rosji. Niewiarygodne statystyki, spóźnione działania, https://www. defence24.pl/koronawirus-w-rosji-niewiarygodne-statystyki-spoznione-dzialania [dostęp: 13 czerwca 2020].
} 
dezinformacyjna przypominała działania ZSRR z lat osiemdziesiatych $\mathrm{XX}$ wieku, kiedy to oskarżano amerykańskie służby wywiadowcze o przyczynienie się do rozwoju wirusa $\mathrm{HIV}^{6}$. Stanowiła ona także kontynuację aktywności radzieckich organów bezpieczeństwa od czasów wojny koreańskiej, kiedy to sugerowano odpowiedzialność armii amerykańskiej za wywoływanie chorób zakaźnych. W kolejnych dekadach zimnej wojny strategia dezinformacji ZSRR była kontynuowana, zaś po rozpadzie sowieckiego mocarstwa aż do rządów Putina - była zawieszona. Wraz z zaostrzaniem retoryki Rosji w kwestiach międzynarodowych, od początku jego drugiej kadencji władze na Kremlu inwestowały coraz większe środki w propagowanie wielu kontrowersyjnych teorii. Epidemia koronawirusa stała się okazją do przedstawiania wielu półprawd oraz kłamstw, czego przykładem jest powielana sugestia o szkodliwości rozwoju sieci 5G. Zdaniem administratorów internetowej strony Odkrywamy Zakryte, wirus ten „wywołuje podobne objawy do zespołu dolegliwości u pacjentów $z$ nadwrażliwością elektromagnetyczną"7. Istotne jest także konsekwentne propagowanie przez Kreml szkodliwości zastosowania możliwych szczepionek na koronawirusa. Wyrażając pogląd, że nakręcanie strachu może przyczynić się do wzrostu zarobków koncernów farmaceutycznych ${ }^{8}$, Moskwa próbuje wytworzyć przekonanie, że pandemia została celowo wywołana, żeby określone grupy powiązane $z$ amerykańskim rządem oraz miliarderem Billem Gatesem mogły na niej zarobić.

Wraz z postępującymi liczbami zarażeń zaczęto jednak skupiać się na walce $z$ niepożądanym zjawiskiem. Pod koniec marca Putin podjał konkretne kroki na rzecz jego powstrzymania ${ }^{9}$. Poziom restrykcji wprowadzono w zależności od regionu, np. zakaz zgromadzeń w Moskwie i w jej okolicach dotyczył powyżej 50 osób, zaś w Sankt-Petersburgu i na jego obrzeżach - powyżej 100 osób ${ }^{10}$. Różnicując obostrzenia, władze rosyjskie obawiały się opozycyjnych manifestacji w stolicy, w której to, w odróżnieniu do Petersburga, grupy przeciwne rządom Putina

6 A. Szabaciuk, Rosyjska kampania dezinformacyjna wobec globalnej pandemii COVID-19, https://ies.lublin.pl/pub/publikacje/komentarze/ies-komentarze-150-53-2020 _2.pdf, „Komentarze IEŚ” 2020, nr 53, s. 1 [dostęp: 19 czerwca 2020].

7 M. Łuniewski, Wirusowe fake newsy $w$ służbie Kremla, https://www.rp.pl/Plus-Minus/304039999-Wirusowe-fake-newsy-w-sluzbie-Kremla.html [dostęp: 20 maja 2020].

8 M. Kacewicz, Rosja: koronawirus zaraża propagande i gospodarkę, https://belsat. $\mathrm{eu} / \mathrm{pl} /$ news/rosja-koronawirus-zaraza-propagande-i-gospodarke/ [dostęp: 23 maja 2020].

9 G. Kuczyński, Nerwy na Kremlu. Putin zniknąt na cztery dni, potem dali wywiad sprzed pół roku, https://www.tvp.info/47962994/nerwy-na-kremlu-putin-zniknal-na -cztery-dni-potem-dali-wywiad-sprzed-pol-roku [dostęp: 11 maja 2020].

10 Koronawirus $w$ Rosji. Niewiarygodne statystyki... . 
sa liczniejsze i bardziej skoordynowane. Strach przed reakcja społeczną był widoczny także w Czeczenii, gdzie prezydent Kadyrow zamknał granice dla reszty kraju i wprowadził godzinę policyjna. Zasugerował także, że osoby naruszające kwarantannę moga zostać stracone ${ }^{11}$. Na radykalne kroki władz rosyjskich wpłyną też przypadek zachorowania wiceszefa administracji prezydenckiej Siergieja Kirijenki, odpowiadającego za próbę przedłużenia rządów Putina i wyzerowania jego dotychczasowych kadencji ${ }^{12}$. W krótkim czasie zarazili się także rzecznik Kremla Dmitrij Pieskow oraz premier Miszustin, co wywołało rosnace spekulacje co do zdrowia samego prezydenta. Przedstawiciele jego administracji zapewniali jednak, że Putin czuje się dobrze i kieruje walką $z$ epidemią. Wyrazem próby zademonstrowania, że stara się on walczyć $z$ wirusem, była jego wizyta w szpitalu izolacyjnym w miejscowości Kommunarka pod Moskwą. Manifestując, że nie obawia się wirusa, rosyjski przywódca stara się przedstawić siebie jako polityka zdecydowanego w odróżnieniu do przywódców zachodnich. Nie ulega watpliwości, że zamieszanie związane $z$ wirusem, przejściowo pomogło Putinowi umocnić swoją władzę w kraju, odwracając uwagę od spadku poparcia społecznego. Jednakże im bardziej liczba zachorowań ulegała zwiększeniu, tym wyraźniej objawiały się rozmaite zaniedbania, charakteryzujace Rosje jeszcze od czasów ZSRR, do których zaliczamy m.in. chronicznie niedofinansowaną służbę zdrowia, brak personelu medycznego, sprzętu, infrastruktury, korupcję, dezorganizację oraz alkoholizm.

Zdajac sobie sprawę $z$ dostrzegania przez społeczeństwo tych problemów, Putin zdecydował się na scedowanie odpowiedzialności za funkcjonowanie tej sfery życia publicznego na lokalne organy administracji państwowej, które już w przeszłości przedstawiano w złym swietle $\mathrm{w}$ trudnych sytuacjach klęsk czy kataklizmów. Podejmując decyzję o odsunięciu się w cień, rosyjski prezydent poczynił działania w dwóch kierunkach. $Z$ jednej strony chciał utwierdzić w społeczeństwie wizerunek siebie jako „dobrego cara”, który jest poza wszelka krytyka poczynań władz $\mathrm{w}$ wypadku ich niedostatecznego charakteru i miernych rezultatów. $Z$ drugiej strony podjął ryzyko zwiększenia usamodzielnienia się władz lokalnych, zwłaszcza w republikach azjatyckich, co może na przyszłość stanowić pewne zagrożenie dla sprawowanych przez niego rządów. Niektóre regiony i republiki w azjatyckiej części Rosji m.in. Kaukaz Północny, wdrażają środki mające

11 M. Russell, Russia and the coronavirus crisis... .

12 G. Kuczyński, Nerwy na Kremlu... . 
powstrzymać koronawirusa bez jakiejkolwiek koordynacji z Moskwa ${ }^{13}$. Można przypuszczać, że nadmierne usamodzielnienie się przywódców takich obszarów administracyjnych i tym samym przejawianie przez nich określonych ambicji politycznych może być nieprzychylnie odbierane przez rosyjskiego prezydenta oraz jego otoczenie.

Za zasadny powinniśmy uznać jednak pogląd, że Putin, kierując odpowiedzialność za walkę $z$ epidemia koronawirusa na niższe szczeble władzy, szczególnie administrację lokalną, przyją złą taktykę, gdyż pokazał swoje odizolowanie od własnych obywateli. Wyrazem braku akceptacji rosyjskiego społeczeństwa wobec takiej praktyki, są dane ośrodka WCIOM (Ogólnorosyjskiego Centrum Badania Opinii Publicznej) powiazanego $z$ władzami na Kremlu. Wynika $z$ nich, że chociaż 70 proc. Rosjan w dalszym ciagu wyraża zaufanie wobec swojego przywódcy ${ }^{14}$, to jednak odnotowuje się trend spadkowy. Sytuację utrzymującej się ufności ułatwia postępująca słabość rosyjskiej opozycji, potęgowana podziałem, aresztowaniami jej przywódców oraz brakiem zrozumienia społeczeństwa dla postulatów opozycyjnych. Rosyjski lider wykorzystał pandemię także do dalszego ograniczania swobód demokratycznych, czego dowodem było odmówienie zagranicznym reporterom dostępu do rosyjskiego parlamentu w czasie jego sesji 19 marca, kiedy to omawiano możliwość przedłużenia rząów obecnej głowy państwa. Chociaż moskiewskie władze obiecały dostarczyć pisemne raporty i udostępnić retransmisje wideo „tam, gdzie to możliwe", rozstrzygnięcie w tej sprawie uznano w końcu za arbitralne i pozbawione przejrzystości ${ }^{15}$. Ponadto już od poczatku marca Roskomnadzor, będący służba państwową sprawująca nadzór nad rosyjska wersja Internetu - Runet, blokował pojawiajace się informacje w mediach społecznościowych dotyczące epidemii, nieprzychylne dla władz w Moskwie ${ }^{16}$. Zmniejszanie zakresu swobód obywatelskich nie spotkało się jednak $z$ szersza reakcja społeczna, gdyż ludzie uznali konieczne zespolenie się wokół rządu w kryzysowej sytuacji. Mając $\mathrm{w}$ pamięci chaos gospodarczy epoki Jelcynowskiej, obywatele w dal-

13 E. Avdaliani, Coronavirus Is Hitting Russia on More than the Economy, https://besacenter.org/perspectives-papers/coronavirus-russia-economy/ [dostęp: 24 maja 2020].

14 Koronawirus $w$ Rosji: władze federalne traca, https://warsawinstitute.org/pl/koronawirus-w-rosji-wladze-federalne-traca/ [dostęp: 25 maja 2020].

15 Russia suppresses coronavirus information at home, manipulates it abroad, https:// rsf.org/en/news/russia-suppresses-coronavirus-information-home-manipulates-it-abroad [dostęp: 21 maja 2020].

16 I. Wiśniewska, Rosja wobec pandemii koronawirusa: pochwała oblężonej twierdzy, https://www.osw.waw.pl/pl/publikacje/analizy/2020-03-18/rosja-wobec-pandemii-koronawirusa-pochwala-oblezonej-twierdzy [dostęp: 25 maja 2020]. 
szym ciagu $z$ dużą dozą nieufności podchodza do prozachodnich demokratów, uważając, że dążą oni do wyprzedania kraju w obce ręce i osobistego wzbogacenia się w ten sposób. Nie można jednak nie ulec wrażeniu, że pozycja kontestatorów Putina może $z$ czasem ulec wzmocnieniu, jeśli nieudolność centralnych władz będzie w dalszym ciagu silnie widoczna. Można dostrzec, że politycy opozycyjni chca pokazać społeczeństwu, że w odróżnieniu do rządzących, stanowia zespół odpowiedzialnych ludzi, którzy chca działać dla dobra wszystkich Rosjan, a nie jedynie dla swojego partykularnego interesu. W ten sposób trzeba rozumieć decyzję Aleksieja Nawalnego o wstrzymaniu protestów w marcu 2020 roku przeciwko planowanemu przedłużeniu rządów Putina. Zaznaczył on, że organizowanie manifestacji w czasie zarazy jest krokiem nieodpowiedzialnym, lecz jednocześnie wezwał do bojkotu głosowania ${ }^{17}$. Mając na względzie znaczna aktywność polityczną opozycjonisty przed wrześniowymi wyborami lokalnymi, $z$ duża doza prawdopodobieństwa można przyjąć, że to władze w Moskwie podjęły decyzję o jego zabójstwie w sierpniu 2020 roku. Wówczas został on zatruty środkiem bojowym nowiczok, podobnie jak pułkownik wywiadu GRU Siergiej Skripal i jego córka na terenie Wielkiej Brytanii w marcu 2018 roku. O odpowiedzialności Kremla może świadczyć fakt, że trucizna była produkowana jeszcze za czasów ZSRR i jest dostępna jedynie w rosyjskim laboratorium. Ponadto niemieccy lekarze, leczący Nawalnego w szpitalu w Berlinie, jednoznacznie potwierdzili, że wobec niego użyto nowiczoka ${ }^{18}$. Jednakże próba otrucia zakończyła się niepowodzeniem.

Obawiając się destabilizacji politycznej w kraju oraz wykorzystując sytuację pandemii absorbującej działania wielu rządów, Putin zdecydował się na wyzerowanie swoich kadencji po 2024 roku pozwalające na dalsze utrzymanie się u steru władzy. Przywódca ten ogłosił 1 czerwca, że głosowanie nad zestawem poprawek do konstytucji, które pozwola mu pozostać na stanowisku do 2036 roku, odbędzie się 1 lipca $^{19}$. Wypada domniemywać, że podejmując taki krok, uważa on siebie nie tyle za jedynego polityka mającego zdolność do utrzymania

\footnotetext{
17 P. Ivanova, A. Osborn, Coronavirus forces Putin critics to scale back protests before big vote, https://uk.reuters.com/article/uk-health-coronavirus-russia-protests/coronavirus-forces-putin-critics-to-scale-back-protests-before-big-vote-idUKKBN2 1724I?feedType $=$ RSS\&feedName $=$ worldNews [dostęp: 1 czerwca 2020].

18 Niemieckie laboratorium: Nawalny otruty Nowiczokiem, https://www.rp.pl/Polityka/ 200909854-PILNE-Niemieckie-laboratorium-Nawalny-otruty-Nowiczokiem.html [dostęp: 26 września 2020].

19 Coronavirus in Russia: The Latest News, https://www.themoscowtimes.com/2020/ 06/01/coronavirus-in-russia-the-latest-news-june-1-a69117 [dostęp: 8 czerwca 2020].
} 
stabilności władzy, ile sądzi, że nikt $z$ jego najbliższych współpracowników nie posiada zdolności i charakteru, żeby utrzymać autorytarny model rząów w Rosji. Nie ulega jednak watpliwości, że dodatkowe kadencje dla już 68-letniego Putina są jedynie graniem na zwłokę w obliczu nieuchronnej zmiany pokoleniowej w Rosji i przejęcia rzadów przez młodszych polityków, także często powiązanych z Federalną Służbą Bezpieczeństwa. W obliczu stopniowej deprecjacji systemu partyjnego (od 2000 r.) oraz minimalnej roli rodziny przywódcy w systemie politycznym, Putin jest skazany na wybór następcy spośród swoich najbliższych współpracowników, którzy wraz $z$ biegiem lat stali się dla niego coraz większym rozczarowaniem. Prezydent Rosji uważa, że wraz z upływem czasu uzależnili się od korzyści wynikających ze sprawowanej władzy i skupili na tworzeniu fortun finansowo-biznesowych, zapominając o najważniejszych interesach międzynarodowych Rosji, związanych $z$ osłabieniem pozycji Stanów Zjednoczonych na świecie, podejmowaniem wewnętrznych prób dezintegracji Unii Europejskiej, wzmocnieniem wpływów na Bliskim Wschodzie, umocnieniem prymatu na obszarze postsowieckim i podjęciem wyzwania dotrzymania kroku rosnącej ekspansji globalnej Chin. Przykładem takich postaw jest wieloletni prezydencki współpracownik, Igor Sieczyn, który, kontrolując sektory energetyczne, dorobił się majątku wyłącznie dzięki powiązaniom $z$ przywódca ${ }^{20}$, jednocześnie coraz mniej zabiegając o interesy państwa. Podobnie byłego premiera Miedwiediewa zagadnienia poprawnego funkcjonowania kraju obchodzily $\mathrm{w}$ coraz mniejszym stopniu. Nikołaj Patruszew $z$ kolei, były dyrektor FSB i szef prezydenckiej administracji - ponoszacy odpowiedzialność za wiele zbrodniczych działań Putina w Czeczenii i eliminację przeciwników politycznych, m.in. Aleksandra Litwinienki - jest człowiekiem niezdolnym do wzbudzenia zaufania wśród ludności. Jego osoba może stanowić też poważny problem dla międzynarodowej reputacji Rosji. Podobnie jak w przypadku większości swoich poprzedników $z$ okresu ZSRR, Putin wyeliminował z życia politycznego dyplomatów samodzielnych i inteligentnych, zdolnych do poprawy pozycji międzynarodowej Ro$\mathrm{sji}$, a zarazem realizujących $\mathrm{w}$ polityce wewnętrznej twarde pryncypia ukształtowane przez autorytarny charakter systemu politycznego, przypisanego od lat temu państwu. W tej sytuacji Putin wykorzystał czas pandemii do utrzymania silnej prezydentury $\mathrm{w}$ swoich rękach

20 M. Gawęda, Igor Sieczin - najlepiej zarabiajacy prezes $w$ Rosji, http://biznes.onet.pl/ wiadomosci/kraj/igor-sieczin-najlepiej-zarabiajacy-prezes-w-rosji/p20bg [dostęp: 16 maja 2020]. 
w dobie kryzysu, co $z$ jednej strony może doprowadzić do ponownego wzrostu jego popularności, ale $z$ drugiej - przyczynić się do upadku autorytetu w społeczeństwie, pociagając za sobą wydarzenia w postaci protestów wobec pogarszającej się sytuacji ekonomicznej i pozbawienia Rosjan pewności otrzymywania pensji oraz emerytur. Powyższe potwierdza Aleksander Baunow, który pisze, że decyzja Putina o pozostaniu u władzy zostanie oceniona w świetle tego, jak poradzi on sobie $z$ epidemią oraz prognozuje, że jeśli Rosja pogrą̇y się w kryzysie, to Putin zostanie zapamiętany nie jako silny przywódca, lecz polityk, który nie powstrzymał rozprzestrzeniania się choroby i nie pomógł dostatecznie sprawnie i kompleksowo własnym obywatelom w trudnych czasach $^{21}$. Jeszcze dalej w swoich analizach posuwa się jeden $z$ analityków z Chatham House, Nikołaj Pietrow, według którego rosyjski autokrata stoi przed poważnym wyzwaniem, ponieważ zaraza niejako przekreśliła wszystkie jego dokonania 20 lat sprawowanej władzy. Pietrow uważa wręcz, że prezydent okaże się w oczach samych Rosjan politykiem $z$ wizją dopiero wtedy, kiedy uda mu się powstrzymać pandemię $^{22}$. Na podstawie dotychczasowego rozwoju sytuacji epidemicznej, właściwe będzie przekonanie, że działania władz rosyjskich nie sa do końca akceptowane w społeczeństwie. Wobec tego można się niestety spodziewać aktywizacji napastliwej polityki zagranicznej Rosji.

\section{POLITYKA ZAGRANICZNA ROSJI W OBLICZU PANDEMII}

Opisując politykę zagraniczna Federacji Rosyjskiej w czasie pandemii, powinniśmy przyjrzeć się perspektywom kształtowania się stosunków Rosji z najważniejszymi podmiotami międzynarodowymi. Pierwszym $z$ nich sa Stany Zjednoczone. Nie ulega watpliwości, że fala zachorowań w tym kraju została dostrzeżona na Kremlu $z$ zadowoleniem, gdyż unaoczniła problemy $z$ ochrona zdrowia i rysujący się kryzys gospodarczy na niespotykaną skalę od lat trzydziestych XX wieku dotykający w głównej mierze czarnej populacji. Sytuacji nie ułatwiaja także rozgrywające się $\mathrm{w}$ wielu miastach wielotysięczne manifestacje, których uczestnicy nie przestrzegają w najmniejszym stopniu jakichkolwiek obostrzeń sanitarnych czy zaleceń w ograniczaniu dystansu

\footnotetext{
${ }_{21}$ А.Баунов, Путин и коронавирус. Что означает эпидемия для российской власти, https://carnegie.ru/commentary/81340 [dostęp: 14 maja 2020].

${ }_{22}$ M.A. Berdy, How Russia's coronavirus crisis got so bad, https://www.politico.eu/article/how-russias-coronavirus-crisis-got-so-bad-vladimir-putin-covid19/ [dostęp: 15 czerwca 2020].
} 
społecznego. Powyższe rozruchy wywołane bezwzględnościa policyjnej interwencji zakończonej śmiercia czarnoskórego Amerykanina, George'a Floyda, odsłoniły nierozwiazane do chwili obecnej problemy społeczne nurtujące społeczeństwo amerykańskie. Zgon mężczyzny i związana $z$ tym fala zamieszek na tle rasowym, połączona $z$ fala przemocy wobec policji - dała argumenty władzom w Moskwie, że Stany Zjednoczone sa państwem niestabilnym wewnętrznie i nietolerancyjnym wobec mniejszości. $Z$ tego też względu, zdaniem moskiewskich publicystów, nie mają one argumentów do narzucania własnej dominacji na świecie. Stąd też niewykluczone pozostaje dalsze zaostrzenie tonu Kremla wobec największego dziś mocarstwa i próba wykorzystania zaistniałej sytuacji do podburzania Amerykanów przed wyborami prezydenckimi w listopadzie 2020 roku. Potwierdzenie tej hipotezy stanowić moga informacje, pojawiające się w mediach światowych, sugerujące, że Moskwa może starać się sfinansować w Afryce szkolenia Afroamerykanów, tworzących niedawny rdzeń elektoratu kandydatki Partii Demokratycznej na prezydenta w wyborach w 2016 roku, Hillary Clinton, w celu podjęcia później przez nich działań sabotażowych przeciwko USA i nawiąania przez nich kontaktów $z$ grupami przestępczymi. Miałyby one pomóc w ewentualnym utworzeniu na południu USA „państwa” afrykańskiego, co w samym założeniu miałoby pogłębić problemy wewnętrzne Stanów. Autorzy dokumentu, do którego dotarła telewizja NBC, zaznaczaja, że jest szansa na zrealizowanie tych planów, ponieważ polityka Trumpa doprowadziła do wysokiej polaryzacji społecznej mieszkańców USA ${ }^{23}$. Niezwykle wymowna w tym kontekście jest wypowiedź prezydenta, który w odpowiedzi na oskarżenia o współudział Rosjan w dezinformacji, powiedział, że to CNN publikuje „fikcyjne wiadomości” i nie dostrzega, że Rosja systematycznie próbuje podburzyć nastroje wśród amerykańskiego społeczeństwa, co nasuwa skojarzenia z założeniami Kremla, realizowanymi jeszcze w czasach zimnej wojny - wskazywaniem na nierówności rasowe w USA, bezprawiem policji, brakiem zdolności rządu w Waszyngtonie do reagowania na aktualna sytuację oraz podsycaniem sprzeczności między Demokratami i Republikanami ${ }^{24}$. Skutkiem tego wydaje się być wzmożenie propagandy, że to Stany Zjednoczone sa odpowiedzialne za wybuch pandemii i sugerowanie, że cały kryzys został

${ }^{23}$ Rosjanie podsycaja zamieszki $w$ Stanach Zjednoczonych? https://www.cyberdefence24.pl/rosjanie-podsycaja-zamieszki-w-stanach-zjednoczonych [dostęp: 15 czerwca 2020].

${ }_{24}$ Russian connection in US riots, https://igtds.org/2020/06/russian-connection-inus-riots/ [dostęp: 20 czerweca 2020]. 
sprowokowany przez Gatesa, mającego rzekomo zmierzać do depopulacji ludności świata, przewidującego jeszcze w 2015 roku wybuch podobnej do obecnej pandemii ${ }^{25}$. Poprzez oskarżanie Amerykanów o zaistniała sytuację Moskwa podważa również zasadność trwania Sojuszu Północnoatlantyckiego, twierdzac, że organizacja ta w dobie pandemii jest nieefektywna. Sugestie o brak wsparcia NATO dla swoich sojuszników można uznać za kłamstwo, gdyż Sojusz ułatwia m.in. Czechom, Włochom, Luksemburgowi, Holandii, Macedonii Północnej, Rumunii, Słowacji i Hiszpanii transport powietrzny sprzętu medycznego i innych materiałów wykorzystywanych w walce $z$ wirusem ${ }^{26}$.

Istotnym kierunkiem dezinformacyjnej propagandy Kremla jest także Europa Zachodnia. Nie ulega watpliwości, że poprzez kryzys koronawirusowy Moskwa będzie dążyła do wzmocnienia tam swoich wpływów i do dalszych podziałów Wspólnoty Atlantyckiej. Deprecjonując znaczenie UE jako uzależnionej od USA struktury politycznej, Kreml próbuje przekonać zachodnią opinie publiczna, że Unia nie jest $\mathrm{w}$ stanie poradzić sobie sama $z$ kryzysem i jest na krawędzi rozpadu. Dodatkowym celem tej propagandy jest przekonywanie odbiorców zachodnich, że systemy opieki zdrowotnej poszczególnych krajów sa niewydolne za sprawa braku odpowiedniego dofinansowania przez nieudolnych przywódców. W kontraście do powyższego rosyjscy propagandziści sygnalizuja, że w walce $z$ wirusem system Putina działa lepiej niż zachodnie demokracje ${ }^{27}$.

Niezwykle symptomatyczna w tym kontekście jest wypowiedź znanego rosyjskiego politologa, Aleksandra Dugina, który wyraził nadzieję, że kryzys koronawirusowy przyczyni się do zakończenia globalizacji i liberalizmu jako zjawisk odpowiedzialnych za niekontrolowany rozwój pandemii. Zdaniem analityka, trwajaca infekcja ma szanse odnowić życie społeczne i przyczynić się do ukształtowania modelu państwa zamkniętego gospodarczo i handlowo $z$ reszta świata ${ }^{28}$. Słowa Dugina koresponduja $z$ wypowiedzia innego analityka, według którego, kraje europejskie i Stany Zjednoczone nie spowolniły

25 B. Cole, Russian State Television Pushes Conspiracy Theory Bill Gates Is Behind Coronavirus Pandemic, https://www.newsweek.com/russian-state-television-pushes-conspiracy-theory-bill-gates-behind-coronavirus-pandemic-1501465 [dostęp: 18 maja 2020].

${ }_{26}$ Russia's Top Five Myths about NATO \& COVID-19, https://www.nato.int/nato_static_fl2014/assets/pdf/2020/4/pdf/2004-Factsheet-Russia-Myths-COVID-19_en.pdf, April 2020, s. 1 [dostep: 23 czerwca 2020].

27 N. Bentzen, COVID-19 foreign influence campaigns Europe and the global battle of narratives, https://www.europarl.europa.eu/RegData/etudes/BRIE/2020/649367/EPRS _BRI(2020)649367_EN.pdf, s. 4 [dostęp: 27 czerwca 2020].

28 A. Szabaciuk, Rosyjska kampania dezinformacyjna... . 
rozprzestrzeniania się tej infekcji zarówno ze względu na stan opieki zdrowotnej, jak i niemożność szybkiej zmiany utrwalonych zachowań populacji ${ }^{29}$. O zaistniała sytuacje Kreml obwiniał zbyt znaczna obecność w Europie Zachodniej imigrantów. Moskwa może wykorzystać pandemię koronawirusa do potwierdzenia swojej wizji polityki tradycyjnych wartości, uważając, że nadmierne przyjęcie przez UE imigrantów i wspomaganie ich finansowo przyczyniło się do kryzysu pandemicznego, gdyż głównych państw UE nie było stać na zapewnienie bezpieczeństwa swoim rodzimym obywatelom. Taka taktyka jest intensywnie stosowana wobec najbardziej poszkodowanych przez chorobę obywateli krajów zachodnich, którzy pośrednio obwiniają nie rządzacych o ich problemy ekonomiczne i nadmierne skupienie się przez władze na pomocy ludziom przybyłym $z$ innych krajów i kręgów kulturowych. Opierając swoja politykę na konserwatywnych wartościach kultywowanych przez m.in. Cerkiew prawosławna kierowana przez patriarchę Cyryla ${ }^{30}$, Kreml stara się pokazać, że w Rosji panuje moralny porządek, w odróżnieniu od Zachodu, w którym zwyciężyła nadmierna tolerancja wobec „odmienności” ${ }^{31}$. Władze w Moskwie promuja pogląd, że wskutek polityki nadmiernej otwartości kanclerz Merkel wobec imigrantów naruszających europejskie wartości w Europie Zachodniej zrodziły się rozliczne problemy, których Unia nie jest w stanie samodzielnie rozwiąać. Kreml podkreśla, że niezdolność do integrowania muzułmańskich imigrantów w europejskich społecznościach jest spowodowana sprzecznościami wewnątrz tej organizacji i brakiem polityków reprezentujących stanowisko przeciwstawiające się nieskoordynowanemu napływowi imigrantów ${ }^{32}$.

Nieprzypadkowo w tym samym czasie w przestrzeni publicznej pojawiła się wypowiedź czołowego propagandzisty Kremla, Dmitrija Kisielowa, według którego koronawirus spowodował całkowity upadek idei Europy ${ }^{33}$. Wyrażając powyższe opinie, władze na Kremlu próbuja

29 Ш. Вебер, Коронавирус: взгляд на российско-китайские отношения сквозь призму политических заявлений, w: Экономическая политика во времена COVID-19, https:// www.nes.ru/files/COVID19(21apr2020).pdf, АПРЕ $Ь$ Ь 2020, s. 48 [dostęp: 27 maja 2020].

30 I. Pacepa, The Secret Roots of Liberation Theology, http://www.nationalreview.com/article/417383/secret-roots-liberation-theology?tar get=author\&tid=901039 [dostęp: 9 czerwca 2020].

31 G. Reid, European Court Condemns Russia's Gay Propaganda Law, https:// www. hrw.org/news/2017/06/22/european-court-condemns-russias-gay-propaganda-law [dostęp: 10 czerwca 2020].

32 P. Bielicki, Federacja Rosyjska a Brexit - szanse i zagrożenia, „Historia i Polityka”, nr 27, Toruń 2019, s. 27-28.

33 Ю. Бершидский, Фейк Дмитрия Киселева: пандемия COVID-19 дала старт развалу Евросоюза, https://theins.ru/antifake/208744?fbclid=IwAR1vydK9Oj7qi4uSrSZgI65-nbjViGJjGVjy1DD1xmjwlvgiSLBMf_hVhqc [dostęp: 12 czerwca 2020]. 
wywołać w rosyjskim społeczeństwie oraz na Zachodzie obraz, że to zachowania Europejczyków i możliwość nieograniczonego przemieszczania się obywateli przyczyniły się w znaczny sposób do rozprzestrzenienia się epidemii. Kreml sugeruje ponadto, że wpływ na pandemię miało także niedostateczne inwestowanie krajów zachodnich i USA w ochronę zdrowia, co można odczytać jako aluzję do potrzeby zmniejszenia takich wydatków na cele wojskowe, a to jest już bezpośrednio w interesie Federacji Rosyjskiej, której zależy na deprecjonowaniu zachodnich zdolności obronnych. Moskwa swoja politykę wobec Europy realizuje poprzez stronnicze platformy dezinformacyjne, blogerów oraz prezentowanie „relacji” Rosjan mieszkajacych w USA, Kanadzie i w państwach europejskich. Co ciekawe, największe rosyjskie platformy sponsorowane przez państwo intensywnie korzystały w okresach wzmożonej aktywności propagandowej $z$ kont nadzorowanych przez żonę Alexandra Ovechkina, znanego rosyjskiego hokeisty, podkreślając też rosnąca panikę i niepewność w Stanach Zjednoczonych, a także brak towarów i surowców. Aspekt ten porównały z rosyjskimi sklepami „pełnymi produktów"34.

Polem realizacji taktyki Kremla okazał się także eksport sprzętu ochronnego przed COVID-19 do pogrążonych w walce $z$ epidemia Włoch. Już w marcu 2020 roku Moskwa zasygnalizowała, że pomoc dla tego kraju obejmie wyposażenie medyczne oraz około stu specjalistów wirusologów mających wcześniej doświadczenie w zwalczaniu Eboli $^{35}$. Jednakże wsparcie dla Włochów miało służyć uświadomieniu społeczności zachodniej, że sankcje wobec Moskwy nie sa konieczne, co potwierdza wypowiedź Putina, który na spotkaniu grupy G7 zaapelował do pozostałych członków organizacji o wstrzymanie restrykcji $\mathrm{w}$ obliczu rozwoju epidemii ${ }^{36}$. Wydaje się, że rosyjska strategia może okazać się skuteczna, czego dowodzą kolejne wypowiedzi włoskich polityków, m.in. byłego wicepremiera Matteo Salviniego, sugerującego zniesienie ograniczeń ekonomicznych wobec Rosji ${ }^{37}$. Włoskie media podaja jednak, że większość przysłanych do Italii ekspertów to specja-

${ }^{34}$ S. Sukhankin, COVID-19 as a tool of information confronation: Russia's approach, https://www.policyschool.ca/wp-content/uploads/2020/03/COVID-19-Tool-of-Information-Sukhankin.pdf, vol. 13, April 2020, s. 3 [dostęp: 25 maja 2020].

${ }_{35}$ Russia begins with drawing military virus experts from Italy, https://www.thelocal. it/20200507/russia-begins-withdrawing-military-virus-experts-from-italy [dostęp: 6 czerwca 2020].

${ }^{36}$ A. Legucka, M. Przychodniak, Dezinformacja Chin i Rosji $w$ trakcie pandemii COVID-19, https://www.pism.pl/publikacje/Dezinformacja_Chin_i_Rosji_w_trakcie_pandemii_ COVID19 [dostęp: 2 czerwca 2020].

37 Russia's Humanitarian Aid to Italy: How Kremlin Uses the Coronavirus Pandemic to Cover up Its Special Operation, https://en.hromadske.ua/posts/russias-humanitarian-a- 
liści od wojny chemicznej, co może nasuwać skojarzenia, że pełnią oni swoja misję $z$ ramienia wywiadu wojskowego GRU. Ponadto, zdaniem dziennika „La Stampa”, około 80 proc. rosyjskich dostaw w ramach pomocy jest „bezużytecznych”, a rosyjska akcja jest nazywana „pretekstem" do zwiększenia swojej obecności we Włoszech ${ }^{38}$. Oskarżenia włoskiej prasy o prowizoryczność rosyjskiej pomocy zostały przyjęte na Kremlu $z$ dezaprobata. Ministerstwo Obrony Federacji Rosyjskiej oskarżyło redakcję „La Stampy” o „chowanie się za ideałami wolności słowa”, aby rozpowszechniać historie przypominające „antyrosyjska propagandę". Co ciekawe, ostry język Kremla został niedwuznacznie skrytykowany przez włoski rząd. W specjalnym oświadczeniu przedstawiciel władz na Kwirynale napisał, że chociaż Rzym jest wdzięczny za wsparcie Moskwy w kluczowym momencie zarazy, to wypowiedzi przedstawicieli rosyjskiego resortu obrony sa nie do zaakceptowania. Zaznaczył, że wolność wypowiedzi i prawo do krytyki sa jednym z fundamentów włoskiej demokracji, zaś Moskwa ma prawo odpowiedzieć na zarzuty, ale w sposób formalny i nie urażający nikogo ${ }^{39}$. Tezę o propagandowym charakterze operacji potwierdza także Sergo Germani, dyrektor Instytutu Nauk Społecznych i Studiów Strategicznych w Rzymie. W jego przekonaniu, Rosja działa na płaszczyźnie wywiadowczej i propagandowej, dążąc do wykorzystania epidemii dla podsycania $\mathrm{w}$ społeczeństwie włoskim nastrojów antyunijnych oraz $\mathrm{w}$ celu zbierania informacji wywiadowczych $\mathrm{w}$ jednym $z$ ważniejszych państw NATO ${ }^{40}$. Zdaniem Hamisha de Brettona-Gordona, Rosjanie moga wykorzystać Włochy jako okazję do przetestowania nowego sprzętu i zebrania danych dotyczacych zarówno wirusa, jak i państwa członkowskiego NATO. Według niego, nie ma żadnej wątpliwości, że na terenie Włoch działaja agenci GRU, którzy będą zakładać lub rozbudowywać sieci wywiadowcze i systematycznie poszerzać swoja aktywnośćc $\mathrm{c}^{41}$. Mimo rosnących wątpliwości co do rzeczywistego charakteru rosyjskiej misji pomocowej, władze włoskiego stowarzyszenia Alpini podziękowali rosyjskim wojskowym za pomoc w walce $z$ chorobą na

id-to-italy-how-kremlin-uses-the-coronavirus-pandemic-to-cover-up-its-special-operation [dostęp: 26 maja 2020].

38 N. Bentzen, COVID-19 foreign influence campaigns Europe... .

39 D. Zaks, Italy and Russia Spar Over Alleged Coronavirus Spies, https://www.themoscowtimes.com/2020/04/03/italy-and-russia-spar-over-alleged-coronavirus-spiesa69869 [dostęp: 11 maja 2020].

40 N. Antelava, J. Iacoboni, The influence operation behind Russia's coronavirus aid to Italy, https://www.codastory.com/disinformation/soft-power/russia-coronavirus-aid-italy/ [dostęp: 27 maja 2020].

41 Ibidem. 
terenie Lombardii. Według Marco Colosio, koordynatora obrony cywilnej w powyższej organizacji, przybycie rosyjskich żołnierzy spotkało się $z$ entuzjazmem ${ }^{42}$. Można odnieść wrażenie, że włoskie społeczeństwo nie dostrzega postępujaccej penetracji rosyjskiego wywiadu, uważajac, w odróżnieniu do państw zachodnioeuropejskich - zwłaszcza Niemiec i Francji - że Rosja i Chiny okazały mu pomoc w szczytowym momencie niszczycielskiej działalności koronawirusa. Spóźniona i niekonsekwentna reakcja UE na wybuch choroby przyczyniła się do intensyfikacji prorosyjskich nastrojów we Włoszech, co skrzętnie wykorzystuja powiąane $z$ Kremlem ośrodki medialne działajace na terenie tego kraju. Interesujacca $\mathrm{w}$ tym kontekście jest wypowiedź jednego $z$ włoskich naukowców Francesco Jubiliego, profesora na Uniwersytecie Fortunato $\mathrm{w}$ Benevento. Już w połowie marca akcentował on dziennikarzowi jednego z prorosyjskich portali, że Włochy sa bardzo rozczarowane działaniem UE, która pozostawiła ich samych $w$ walce $z$ epidemia. Zaznaczył także, że jeśli Wspólnota nie zmieni swojej polityki, to nie ma sensu, żeby Włochy pozostały jej członkiem, tym bardziej, że Rzym dopłaca każdego roku miliardy euro do unijnego budżetu ${ }^{43}$.

Przybierające na sile tendencje do całościowego uregulowania stosunków z Moskwą występują również w Niemczech. Ze względu na postępujace załamywanie się tamtejszej gospodarki politycy coraz częściej domagają się od kanclerz Merkel oraz jej współpracowników zniesienia restrykcji nałożonych na Rosję. Argumentem potwierdzajacym takie postawy sa wypowiedzi Waldemara Gerdta ze skrajnie prawicowej Alternatywy dla Niemiec oraz Alexandra Noy, lewicowego posła do Bundestagu. Obaj politycy potępiaja sankcje przeciwko Rosji, które przynosza, ich zdaniem, efekt przeciwny do zamierzonego i szkodliwy dla niemieckich przedsiębiorstw ${ }^{44}$. Gerdt podkreśla, że powinny one zostać anulowane $z$ zwiąku $z$ kryzysem spowodowanym przez koronawirusa. Dlatego też uważa on, że należy przywrócić całościowy handel $z$ Rosja, co przyniesie korzyść całemu światowemu systemowi gospodarczemu ${ }^{45}$. Nie można wykluczyć, że to właśnie

${ }^{42}$ Italian Alpini have congratulated Russian servicemen who are helping in the fight against coronavirus in Lombardy on the upcoming Easter, https://eng.mil.ru/en/news_page/ country/more.htm?id=12286701@egNews [dostęp: 5 czerwca 2020].

43 Ф. Джубили, Италия разочарована реакиией Евросоюза на коронавирус итальянский эксперт, https://eurasia.expert/italiya-razocharovana-reaktsiey-es-na-koronavirus/ [dostęp: 11 czerwca 2020].

44 S. Sukhankin, COVID-19 as a tool of information confronation... .

45 Э.Байназаров, Здоровый смысл: на фоне COVID-19 в ФРГ призвали снять с России санкиии, https://iz.ru/987993/elnar-bainazarov/zdorovyi-smysl-na-fone-covid-19-v-frgprizvali-sniat-s-rossii-sanktcii?utm_source=yxnews\&utm_medium=desktop\&utm_referrer=https\%3A\%2F\%2Fyandex.ru\%2Fnews [dostęp: 10 czerwca 2020]. 
Niemcy mogą w nieodległej przyszłości stać się jednym $z$ ważniejszych obszarów akcji dezinformacyjnej Moskwy, gdyż w obliczu nieuchronnego odejścia kanclerz Merkel $z$ urzędu i problemów $z$ wyznaczeniem jej następcy w gronie rządzącej partii chadeckiej CDU/CSU, istnieja znaczne większe szanse na wzrost fraternizacji niemieckich elit politycznych z Rosja. Ewentualny sojusz niemiecko-rosyjski, możliwy $\mathrm{w}$ dobie wycofania się części wojsk amerykańskich $z$ Niemiec, może stanowić istotne zagrożenie dla zachodnioeuropejskich struktur politycznych i ekonomicznych, co może przyspieszyć realizację planów Kremla dążącego do skłócenia ze sobą krajów Europy Zachodniej i jej podziału.

W sferze tematyki, będącej przedmiotem niniejszego studium, niezwykle istotne sa także perspektywy relacji Rosji z Chinami. Putin, $z$ jednej strony postrzega wzrastajace na arenie międzynarodowej wpływy Pekinu jako przeciwwagę dla napiętych stosunków ze Stanami Zjednoczonymi, a $z$ drugiej strony obawia się tychże wpływów na obszarze Syberii. Stąd też przez cały okres najbardziej intensywnej fali rozwoju epidemii starał się nie krytykować Chińczyków. Chociaż podjał on szybkie kroki dotyczace zamknięcia granicy z Państwem Środka, to jednak utrzymywał dystans wobec oskarżenia chińskich komunistów o przyczynienie się do zaistniałej sytuacji epidemicznej. Wraz z upływem czasu i stopniowym pokonywaniem wirusa przez Chiny Putin $z$ coraz większym uznaniem podchodził do posunięć Pekinu, próbujac deprecjonować odpowiedzialność chińskich władz za rozprzestrzenianie się koronawirusa. W czasie rozmowy z prezydentem ChRL Xi Jinpingiem 19 marca rosyjski prezydent powiedział, że „Chiny dały przykład całej społeczności międzynarodowej, wyraźnie reagujac na prowokację i stygmatyzację pewnej potęgi”, mając na myśli Stany Zjednoczone. Rosyjski przywódca wyraził także „nieskończona wdzięcznośc” rządowi chińskiemu za podjęcie skutecznych działań, powstrzymujacych wirusa w swoim kraju, ale także za promocję zdrowia i bezpieczeństwa ${ }^{46}$. Wyraźnie widać, że oskarżając Stany Zjednoczone o niedostateczne działanie na polu ograniczenia choroby, Putin próbuje przypodobać się Chinom, dażąc do rozmycia ich odpowiedzialności. Ważne jest, że Rosja czynnie partycypuje w przybierajacej na sile propagandzie chińskiej skierowanej wobec Stanów Zjednoczonych, sugerującej amerykańską odpowiedzialność za pandemię i możliwość użycia przez USA broni biologicznej wobec Chin w postaci

46 Ш. Вебер, Коронавирус: взгляд на российско-китайские отношения... . 
COVID-1947. Rosyjski prezydent, unikajac oskarżania Chin, zdaje sobie sprawę, że układ jednobiegunowy - ukształtowany na świecie po 1991 roku i dominacja Stanów Zjednoczonych - odchodzi stopniowo do przeszłości i że to Chiny stana się głównym hegemonem na arenie międzynarodowej. Poza tym należy przyznać, że $z$ podziwem odniósł się do zdecydowanych działań chińskiego rządu komunistycznego wobec własnych obywateli sprzeciwiających się zaleceniom władz $\mathrm{w}$ sprawie przymusowej kwarantanny. Dążący do zwiększenia kontroli nad własnym społeczeństwem Putin rozumie, że wprowadzenie podobnych metod rządzenia nie będzie takie proste, gdyż niezależnie od tradycji autorytarnych i totalitarnych rząów w czasach carskich i ZSRR, Rosjanie sa jednak w dalszym ciagu mniej posłuszni i skłonni do kolektywnej dyscypliny niż Chińczycy czy Koreańczycy ${ }^{48}$. Wreszcie należy stwierdzić, że Putin unika bezpośredniego starcia $z$ Chinami $z$ obawy przed wzrostem chińskich wpływów na Syberii, gdzie coraz większa liczba obywateli Państwa Środka osiedla się na jej bezkresnych i niezamieszkałych obszarach. Ewentualny sprzeciw Kremla wobec takich praktyk komunistycznego reżimu może powodować niekontrolowany napływ jeszcze liczniejszej rzeszy Chińczyków do Rosji, którzy z czasem zaczęliby podważać podstawy rosyjskiego systemu politycznego i społecznego na zajętych przez siebie terenach.

Niewykluczone jest także w kontekście innych uczestników geopolityki światowej, że w dobie pogarszania się notowań Putina, zechce on podążyć droga ponownego zaostrzenia napięcia międzynarodowego w obszarach uznawanych przez Moskwę za strefę swoich partykularnych interesów. Taka taktyka może być realizowana zwłaszcza na Ukrainie oraz na Bliskim Wschodzie. Chociaż w obu tych miejscach sytuacja uległa względnemu uspokojeniu, to nie można wykluczyć, że w przypadku kumulacji uwagi państw zachodnich na własnych sprawach wewnętrznych, Moskwa będzie zmierzać do eskalacji działań wojennych i zapewnienia sobie lepszej pozycji przetargowej w rokowaniach pokojowych. Możliwym jest, że po opanowaniu pandemii koronawirusa Kreml wzmocni presję na Turcję oraz Iran, w celu utrzymania u władzy prezydenta Syrii, Baszara El-Asada. W kwestii tej rosyjski rząd może mieć ułatwione zadanie, ponieważ Iran po zabójstwie przez amerykańskie lotnictwo czołowego wojskowego i polityka reżimu w Teheranie, gen. Kasema Sulejmaniego - także ze względu na pogłębiające się problemy gospodarcze wywołane sankcjami USA,

47 A.Legucka, M. Przychodniak, Dezinformacja Chin i Rosji... .

48 А.Баунов, Путин и коронавирус. Что означает эпидемия... . 
znacznym spadkiem ceny ropy naftowej oraz licznymi przypadkami zachorowań i zgonów na COVID-19 - może być zmuszony do ograniczenia swojej aktywności militarnej poza granicami kraju. Rzad w Teheranie będzie musiał skupić się na kwestiach zdrowotnych, dążyć do zwiększenia świadomości społecznej w zakresie promocji zdrowia i zapobiegania wszelkim chorobom ${ }^{49}$. Osłabienie zainteresowania konfliktem w Syrii może mieć miejsce również w Turcji. Gospodarka w tym kraju poniosła dużo mniejsze straty niż np. irańska, a stosunek zgonów wywołanych pandemia do całkowitej liczby przypadków był tu dwa razy mniejszy niż w Stanach Zjednoczonych i aż siedmiokrotnie mniejszy niż we Francji ${ }^{50}$. Może to zwiastować szybszy powrót do normalności i tym samym do agresywnej polityki zagranicznej wobec Syrii oraz Libii. Obecnie jednak strona turecka uznaje dominująca rolę Rosji na Bliskim Wschodzie, co potwierdzaja dwustronne porozumienia sygnowane $\mathrm{w}$ Libii. Pomimo tego Kreml jest zmuszony do współpracy z Ankara na przedmiotowym obszarze ${ }^{51}$.

Wzrost znaczenia Moskwy w sferze globalnej doprowadzi także do nasilenia jej agresywnej retoryki w aspekcie propagowania własnej wizji historii, zwłaszcza okresu II wojny światowej. Potwierdzeniem podejmowania takich działań jest dla przykładu chociażby nota rosyjskiego MSZ do rządu Finlandii, w której czytamy, że Finowie powinni zapłacić Rosji odszkodowania za opowiedzenie się po stronie Rzeszy niemieckiej w czasie II wojny światowej ${ }^{52}$. Dodatkowo szokować może inicjatywa rosyjskiego deputowanego z 1 czerwca 2020 roku, który zgłosił potrzebę całkowitej rehabilitacji paktu Ribbentrop-Mołotow ${ }^{53}$, co stanowi niebezpieczny precedens wobec krajów Europy Środkowej, ponieważ utwierdza je w przekonaniu, że rosyjscy politycy identyfikują się $z$ działaniami Stalina i Mołotowa i kierują się w swoich przedsięwzięciach planami ponownego podziału Europy. Niewykluczona jest

${ }^{49}$ A.Raoofi, A.Takian, A.A Sari, A. Olyaeemanesh, H. Haghighi, M. Aarabi, COVID-19 Pandemic and Comparative Health Policy Learning in Iran, „Archives of Iranian medicine” 2020, nr 4, s. 225.

50 M. Bryza, Turkey seems to avoid COVID-19 nightmare, https://www.atlanticcouncil. org/blogs/turkeysource/turkey-seems-to-avoid-covid-19-nightmare/ [dostęp: 10 czerwca 2020].

${ }_{51}$ J. Benedyczak, Znaczenie Turcji w polityce Federacji Rosyjskiej, https://www.pism. pl/publikacje/Znaczenie_Turcji_w_polityce_Federacji_Rosyjskiej [dostęp: 27 czerwca 2020].

${ }^{52}$ W Rosji chca oskarżyć Finów o ludobójstwo w czasie II wojny światowej, https:/ / belsat.eu/pl/news/w-rosji-chca-oskarzyc-finow-o-ludobojstwo-w-czasie-ii-wojny-swiatowej/ [dostęp: 22 maja 2020].

${ }_{53}$ W Rosji podjęto próbe rehabilitacji Paktu Ribbentrop-Mołotow. Jest projekt ustawy, https:/ / zw.lt/ kultura-historia/w-rosji-podjeto-probe-rehabilitacji-paktu-ribbentrop-molotow-jest-projekt-ustawy/ [dostęp: 10 czerwca 2020]. 
również intensyfikacja napastliwych przedsięwzięć Moskwy przeciwko Polsce. Jednym z przykładów rosyjskiej dezinformacji wobec Warszawy stały się doniesienia o blokowaniu przez Polskę rosyjskiej pomocy medycznej dla pograżonych w walce $z$ epidemią Włoch. Według Aleksieja Puszkowa, wpływowego rosyjskiego polityka:

Polska nie przepuściła rosyjskich samolotów z pomoca dla Włoch poprzez swoja przestrzeń powietrzna. Jest to podłość na poziomie polityki publicznej. Tym bardziej, że pomoc trafiła do sojusznika Polski w UE i NATO. Odtąd Rosja nie powinna wychodzić Polsce naprzeciw. W niczym!

W odpowiedzi na takie zarzuty, przedstawiciele władz polskich oznajmili, że strona rosyjska w żaden sposób nie składała jakiegokolwiek wniosku o zgodę na wlot $\mathrm{w}$ polska przestrzeń powietrzną ${ }^{54}$. Rosyjski komunikat miał na celu jedynie próbę skłócenia Polski z innymi krajami europejskimi i doprowadzenie do izolacji Warszawy. Niezaprzeczalnie staje się też jawnym utrwalanie narracji moskiewskich elit politycznych sugerujących, że to państwo polskie jest współodpowiedzialne za wybuch II wojny światowej.

Polem aktywności Kremla pozostaje niezmiennie Białoruś. Właściwe będzie stwierdzenie, że kryzys związany z koronawirusem, może przyczynić się do przyspieszenia planów wymuszonej integracji Moskwy z Mińskiem. Świadczy o tym stwierdzenie w publikacji „Kommiersantu" z 1 kwietnia 2020 roku, że prezydent Łukaszenka, lekceważąc problem pandemii, „na wszelki wypadek” prosi jednak Rosje o pomoc w jej zwalczaniu ${ }^{55}$. W mediach rosyjskich pojawiły się informacje sugerujące, że władze $\mathrm{w}$ Mińsku nie radzą sobie $z$ wirusem, ukrywając rzeczywistą liczbę przypadków zakażenia, działają w sposób nieodpowiedni i spóźniony oraz zmuszają lekarzy do stawiania chorym diagnozy ostrej infekcji wirusowej układu oddechowego zamiast rozpoznania koronawirusa ${ }^{56}$. Wypada przypuszczać, że upublicznianie takich informacji ma na celu pokazanie zarówno rosyjskiemu, jak i białoruskiemu społeczeństwu, że jedynie ścisła integracja polityczna i ekonomiczna Białorusi z Rosja, może przyczynić się do skuteczniejszego działania białoruskich władz w przezwyciężeniu

${ }^{54}$ J. Sabak, Polska nie blokuje rosyjskich lotów humanitarnych do Włoch. Koronawirus narzędziem propagandy Kremla [komentarz], https://www.defence24.pl/polska-nie-blokujerosyjskich-lotow-humanitarnych-do-wloch-koronawirus-narzedziem-propagandy-kremla -komentarz [dostęp: 28 maja 2020].

55 O. Kevere, Coercion to Self-Isolation. All the Kremlin's Men Went Out to Fight COVID-19 in Belarus, https://visegradinsight.eu/coercion-to-self-isolation-covid19-belarus/ [dostęp: 24 maja 2020].

56 Ibidem. 
epidemii. Tak prowadzona rosyjska akcja medialna ma za zadanie ośmieszyć Łukaszenkę i przedstawić go jako przywódcę nieudolnego i nie rozumiejącego powagi sytuacji oraz pokazać, że jedynie Rosja zdolna jest przyjść Białorusi z pomoca. Bogdan Bezpalko, czołowy dygnitarz rosyjski, odpowiadajacy za kwestię integracji z Białorusia, powiedział otwarcie:

Jeśli Łukaszenka nadal prosi Rosję o pomoc lekarzom, konieczne jest wysyłanie wyłącznie lekarzy wojskowych, tak jak we Włoszech. Powinny istnieć samochody pomalowane trójkolorowo [kolory flagi rosyjskiej], aby można było zobaczyć, że Rosjanie przybyli na ratunek [...] Misja humanitarna polegająca na pomocy w zwalczaniu koronawirusa powinna być okazja, aby przypomnieć Białorusi o roli Rosji w jej losie ${ }^{57}$.

Wyrazem zaostrzenia rosyjskiego stanowiska jest także podpisanie w maju br. przez Miszustina dekretu precyzującego zakaz importu ropy, co może odbić się w poważny sposób na białoruskiej gospodar$\mathrm{ce}^{58}$, pomimo faktu, że 11 maja na Białoruś dostarczony został transport 80 tysięcy ton ropy naftowej $z$ Arabii Saudyjskiej. ${ }^{59}$ Wysoce niepewna jest również przyszłość Ukrainy. Coraz wyraźniej w otoczeniu prezydenta Wołodymyra Zełenskiego jest wyrażany poglad, że jedynie pertraktacje $z$ Kremlem moga przyczynić się do zakończenia konfliktu, trwającego już przecież od 2014 roku. Ten rządzący Ukraina polityk w coraz większym stopniu przejawia gotowość do daleko idących ustępstw względem prorosyjskich separatystów, sugerując możliwość rokowań $z$ nimi w różnych formach ${ }^{60}$, co samo w sobie stanowi już sukces władz na Kremlu, znających narastające i w części przez siebie kreowane problemy ukraińskiej gospodarki oraz nierealizowanie reform mogacych ten stan poprawić. Jednak ze względu na dominację oligarchów w życiu politycznym i społecznym w dalszym ciagu sa one odkładane w czasie. Niewykluczony stał się nawet scenariusz, że władze w Kijowie uznaja przedstawicieli Donieckiej i Ługańskiej Republiki Ludowej jako przywódców oddzielnych republik, co może oznaczać wstęp do oczekiwanej przez Moskwę i usilnie propagowanej

57 Ibidem.

58 A. Szabaciuk, Białorusko-rosyjska rozgrywka geostrategiczna $z$ importem ropy naftowej $w$ tle, „Komentarze IEŚ 2020, nr 99, https://ies.lublin.pl/pub/publikacje/komentarze/ies-komentarze-196-99-2020.pdf, s. 2 [dostęp: 22 czerwca 2020].

59 Ibidem.

60 B. Bodalska, Prezydent Ukrainy: Nie mamy wyboru - musimy rozmawiać z Rosja, https://www.euractiv.pl/section/polityka-zagraniczna-ue/news/prezydent-ukraina-nie -mamy-wyboru-musimy-rozmawiac-z-rosja-putin-krym-donbas-zelenski/ [dostęp: 17 czerwca 2020]. 
federalizacji kraju. W odbiorze mieszkańców Donbasu, polityka władz ukraińskich jest wysoce nieudolna i skłania ich do twierdzeń o konieczności dalszego zacieśnienia więzi z Rosją ${ }^{61}$.

Niezależnie od powyższych twierdzeń, rysuje się jednak pewna możliwość zmiany niektórych elementów polityki zagranicznej Rosji. Co prawda, rosyjscy naukowcy, Siergiej Karaganow oraz Dimitrij Susłow, podkreślaja zgodnie $z$ linią Kremla, że epidemia nasila negatywne procesy na arenie międzynarodowej, m.in. zaostrzenie rywalizacji między wielkimi mocarstwami czy walkę o przywództwo w świecie, to jednocześnie moga się pojawić zjawiska pozytywne, charakteryzujace się zwiększonym zapotrzebowanie na wspólna walkę $z$ globalnymi wyzwaniami, co może w dłuższej perspektywie korzystnie wpłynąć na sytuację międzynarodowa. Analitycy uwypuklaja, że pandemia unaoczniła konieczność wdrożenia nowych pomysłów na rozwój rosyjskiej polityki zagranicznej, odpowiadających głównym trendom rozwoju świata. Wysuwaja oni wręcz wniosek, że idea wielobiegunowości, lansowana przez Moskwę, nie jest już w większości atrakcyjna dla krajów świata ${ }^{62}$. Twierdzą dalej, że polityka zagraniczna Rosji powinna opierać się na następujaccej triadzie ideologicznej: zachowaniu pokoju międzynarodowego; promowaniu swobody wyboru modeli rozwoju, wspieraniu suwerenności i różnorodności, przeciwdziałaniu wszelkiej hegemonii ideologicznej, politycznej i w sferze wartości, pozycjonowaniu Rosji jako gwaranta „nowego niezaangażowania”; wspólnej ochronie środowiska i walce $z$ nowymi globalnymi wyzwaniami, w tym pandemiami; promowaniu nowej filozofii rozwoju opartej na ratowaniu ludzkiego środowiska, a przede wszystkim samego człowieka, koncentrujacej się na jego zdrowiu moralnym i fizycznym, a nie na niekończącym się wzroście konsumpcji63. Kontrowersyjny jest jednak pogląd autorów artykułu zamieszczonego w „Foreign Affairs”, którzy podnosza argument, że w celu deeskalacji konfliktu między Rosja a Zachodem obie strony powinny zawrzeć umowę, polegająca na tym, że kraje zachodnie nie będą rozszerzały NATO i UE na wschód, a w zamian Rosja nie będzie ingerowała w sytuację w krajach zachodnich ${ }^{64}$.

61 K. Nieczypor, Hybrydowa kwarantanna. Samozwańcze republiki Donbasu wobec pandemii, https://www.osw.waw.pl/pl/publikacje/komentarze-osw/2020-05-08/hybrydowa-kwarantanna-samozwancze-republiki-donbasu-wobec [dostęp: 21 maja 2020].

62 С. Караганов, Д. Суслов, Россия в мире после коронавируса: новые идеи для внешней политики, https://globalaffairs.ru/articles/rossiya-mir-koronavirus-idei/ [dostęp: 5 czerwca 2020].

63 Ibidem.

64 J. Lind, D.G.Press, Reality Check. American Power in an Age of Constraint, „Foreign Affairs" 2020, vol. 99, nr 2, s. 44. 
Jednak ze względu na wieloletni charakter rosyjskiej polityki zagranicznej dążącej do zdobywania wpływów we wszystkich zakątkach globu, zmaterializowanie powyższego scenariusza jest mało prawdopodobne. O nastrojach na Kremlu niech świadczy fakt, że 2 czerwca 2020 roku Putin ogłosił nowa doktrynę nuklearna Rosji zakładająca dalszy rozwój potencjału atomowego kraju. Dokument zakłada koordynację zamierzeń sformułowanych jeszcze w grudniu 2014 roku. Wówczas rosyjski prezydent zadeklarował zdolność do militarnego przeciwstawienia się Stanom Zjednoczonym, wprowadzając zapisy o odstraszaniu nuklearnym do oficjalnego dokumentu rządowego ${ }^{65}$. Władze rosyjskie precyzuja w nim, że Rosja może użyć broni atomowej, jeśli zostanie zaatakowana przez inne państwo, a politykę odstraszania nuklearnego scharakteryzowano jako działanie służące zachowaniu suwerenności Rosji ${ }^{66}$. Musimy zaznaczyć, że koronawirus w Federacji Rosyjskiej nie zmniejszył wydatków na poszczególne, ważne dla rosyjskiej polityki zagranicznej, sektory, m.in. na wojsko. W dalszym ciagu planowo pracuja rosyjskie fabryki zbrojeniowe oraz utrzymany jest na wrzesień 2020 roku termin manewrów pod kryptonimem Kaukaz $2020^{67}$. Perspektywy co do wystarczajacego poziomu rozwoju gospodarczego Rosji w odniesieniu do stawianych sobie celów budzą uzasadnione obawy władz - o czym kilka zdań poniżej.

\section{SYTUACJA EKONOMICZNA ROSJI W DOBIE PANDEMII I PERSPEKTYWY NA PRZYSZŁOŚĆ}

W publikacji nie można pominąc ekonomicznych oddziaływań pandemii koronawirusa na system gospodarczy Federacji Rosyjskiej. Niepokój o jego przyszłość jest widoczny tym bardziej, że w ostatnich latach inflacja oraz deficyt budżetowy silnie wzrastały ${ }^{68}$, a problemy związane $z$ niskimi cenami ropy naftowej - stanowiącej podstawę dla budżetu - nabrały wyjątkowego znaczenia. Dlatego istotnym problemem stały się dla Kremla napięcia w stosunkach z Arabią Saudyj-

65 V. Konyshev, A. Sergunin, Military, w: Routledge Handbook of Russian Foreign Policy, A.P. Tsygankov (red), Routledge 2018, s. 171.

66 Putin zatwierdził nowa doktryne użycia broni nuklearnej, https://www.gazetaprawna.pl/artykuly/1480857,putin-zatwierdzil-nowa-doktryne-uzycia-broni-nuklearnej.html [dostęp: 4 czerwca 2020].

67 W. Radziwinowicz,Armii Rosji koronawirus nie bierze. Siły zbrojne otrzymuja nowa broń, szykuja się do manewrów i defilad, https://wyborcza.pl/7,75399,25988344,armiirosji-koronawirus-nie-bierze-sily-zbrojne-otrzymuja-nowa.html?disableRedirects=true [dostęp: 24 czerwca 2020].

68 E. Avdaliani, Coronavirus Is Hitting Russia... . 
ska $\mathrm{w}$ sprawie cen ropy $\mathrm{w}$ ramach OPEC. Oba podmioty rozpoczęły w marcu 2020 roku wojnę cenowa, zwiększając wydobycie i obniżając ceny w nadziei na uzyskanie większego udziału w rynku. Co prawda, zobowiązały się potem powstrzymać wrogie wobec siebie działania, ale nie wcześniej niż przed zapełnieniem ropa światowych magazynów ${ }^{69}$. Warto zaznaczyć, że napięcia w przedmiotowej kwestii między Moskwa a Rijadem występowały już od pewnego czasu. Przyczynił się do nich spadek cen surowca w drugiej połowie 2018 roku ze względu na wzrost wydobycia $z$ pokładów gazu łupkowego w Stanach Zjednoczonych i obawy o niejasne wówczas perspektywy możliwych konfiguracji rozwoju sytuacji w Iranie po przywróceniu amerykańskich sankcji na reżim ajatollahów. Ostatecznie jednak kraje OPEC w grudniu 2018 roku osiagnęły porozumienie, według którego zgodzono się na ograniczenia wydobycia ropy do poziomu 1,2 miliona baryłek dziennie ${ }^{70}$.

Wraz $z$ wybuchem pandemii zawirowania związane $z$ rozedrganiem cen ropy naftowej przyczyniły się do eskalacji problemów gospodarczych Rosji, zwłaszcza w obszarze handlu zagranicznego. Zdaniem Alexandra Knobela, dyrektora Instytutu Międzynarodowej Ekonomii i Finansów Akademii Handlu Zagranicznego Ministerstwa Rozwoju Gospodarczego Rosji, pandemia koronawirusa mocno i negatywnie wpływa na wymianę handlowa. Przewidywany spadek eksportu towarów rosyjskich za granicę wyniesie niemal 100 miliardów dolarów w 2020 roku, a w ostatecznym rozrachunku nawet 310-320 miliardów. $\mathrm{Za}$ istniejacy stan rzeczy odpowiadaja przede wszystkim niskie ceny surowców - ropy i gazu oraz nałożone sankcje. Odnosząc się z kolei do importu towarów do Rosji, Knobel stwierdza, że jego deprecjacja wyniesie blisko 30-35 proc., co oznaczać będzie, że wartość importowanych produktów spadnie $z 255$ miliardów do około 180-190 miliardów dolarów. Cytowany funkcjonariusz państwowy szacuje, że w największym stopniu dekoniunktura dotyczyć będzie importu dóbr inwestycyjnych - około 35-40 proc., a najmniej - żywności i dóbr konsumpcyjnych - około 20-30 proc. ${ }^{71}$ Przedmiotem zainteresowania rosyjskich ekonomistów stał się również wysoce prawdopodobny, jeśli nie wręcz

69 J. Worland, Oil Prices Won't Be Negative Forever. But the Oil Industry Will Never Be the Same, https://time.com/5824263/coronavirus-negative-oil-prices-consolidation/ [dostęp: 16 czerwca 2020].

70 M. Bradshaw, T. van de Graaf, R. Connolly, Preparing for the new oil order? Saudi Arabia and Russia, „Energy Strategy Reviews” 2019, nr 26, s. 6.

71 П. Химшиашвили, И. Ткачёв, Е. Сухорукова, А. Гальчева, Влияние вируса на поставки товаров из Италии в Россию. Что важно знать, https://www.rbc.ru/economics / 31/03/2020/5e81daa79a7947b429f52b75https: / /www.rbc.ru/economics / 31/03/2020/5e81daa79a7947b429f52b75 [dostęp: 18 maja 2020]. 
pewny, wzrost deficytu budżetowego. Według wstępnych danych Banku Rosji, nadwyżka na rachunku bieżącym bilansu płatniczego w pierwszym kwartale 2020 roku, w porównaniu do analogicznego kwartału ubiegłego roku, zmniejszyła się o ponad jedna trzecia z 33,6 do 21,7 miliarda dolarów, głównie za sprawą niższych przychodów ze sprzedaży surowców energetycznych oraz malejącego nań popytu w Chinach w okresie styczeń-luty ${ }^{72}$. Inne dane także potwierdzaja nabrzmiewajace problemy rosyjskiej gospodarki. W czerwcu 2020 roku Międzynarodowy Fundusz Walutowy przewidywał realne tempo wzrostu PKB Rosji na poziomie minus 6,6 proc. w 2020 roku $^{73}$. Podobne wartości podaje agencja ratingowa Moody's, która w kwietniowym komunikacie ogłosiła, że PKB Rosji może spaść o 5,5 proc. w 2020 roku, przy stosunkowo niewielkim wzroście o 2,2 proc. w $2021 \mathrm{roku}^{74}$. Czołowy rosyjski ekspert do spraw ekonomicznych Andrei Kudrin, ostrzegł niedawno, że gospodarka jego kraju może skurczyć się w bieżącym roku nawet o 8 proc. ${ }^{75}$ Inne prognozy Banku Rosji z kwietnia wskazują na mniejszą skalę regresji - od 4 do 6 proc. ${ }^{76}$ Wydaje się, że powyższe dane potwierdzają niedostateczne przygotowanie rosyjskiej gospodarki na nagły kryzys, co skądinąd nie powinno dziwić, biorąc pod uwage podobne kłopoty $\mathrm{w}$ innych krajach w obliczu konieczności wprowadzenia $\mathrm{w}$ nich szeregu epidemicznych obostrzeń powodujących załamanie się wielu sektorów przemysłu, handlu i usług. Według przedstawicieli Banku Rosji, charakterystyczna cechą obecnej sytuacji jest szybkość i głębokość szoku makroekonomicznego spowodowanego wprowadzeniem niezbędnych działań w celu ograniczenia zakażenia koronawirusem ${ }^{77}$. Niepokój pogłębia fakt, że zaproponowany przez Putina pakiet pomocy dla przedsiębiorców w wysokości 4 miliardów dolarów okazał się niewystarczajacy ${ }^{78}$. O pesymistycznych nastrojach wśród rosyjskich przedsiębiorców niech świadczy informacja, że stowarzyszenia firm zajmujacych się zakupami internetowymi, handlem detalicznym, gastronomia i dziewięcioma innymi branżami wysłały list do premiera Miszustina, w którym ostrze-

72 Обзор финансовой стабильности. Информаиионно-аналитический материал IV квартал 2019 - I квартал 2020 года, Moskwa 2020, s. 17.

${ }^{73}$ IMF expects $6.6 \%$ decline in Russian GDP in 2020, https://news.ru/en/economics / imf-predicts-6-6-decline-in-russian-gdp-in-2020/ [dostęp: 29 czerwca 2020].

74 Moody's: Russian GDP to Decline by 5.5\% This Year, https://russiabusinesstoday. com/economy/moodys-russian-gdp-to-decline-by-5-5-this-year/ [dostęp: 19 maja 2020].

75 M. Russell, Russia and the coronavirus crisis..., s. 2.

76 Обзор финансовой стабильности..., s. 5.

77 Ibidem, s. 39.

78 A. Legucka, Rosja wobec pandemii COVID-19... . 
gali o możliwym załamaniu prowadzonej przez siebie działalności i prosili o liczne dodatkowe środki wsparcia ${ }^{79}$. Nie można jednak wykluczyć, że władze rosyjskie celowo unikają udzielenia szczegółowych informacji dotyczacych wsparcia dla dużych firm, gdyż moga one ujawnić skorumpowany system przyznawania pieniędzy oraz preferencyjnych pożyczek oparty na znajomości z prezydentem Federacji Rosyjskiej oraz innymi współrządzącymi politykami. Pogląd powyższy wyraził profesor Uniwersytetu w Chicago Konstantin Sonin ${ }^{80}$. Problemem dla państwa rosyjskiego stają się także migranci z Azji Środkowej, którzy należą do grupy najbardziej dotkniętych pandemią. Istnieją doniesienia o migrantach, którzy musieli opuścić wynajmowane mieszkania $^{81}$. Zdaniem przedstawicieli organizacji przedsiębiorców Opora Rosji, firmy przygotowują się do zwolnień wielu tysięcy migrantów, zwłaszcza nie zatrudnionych na podstawie żadnej umowy. W nieco lepszej sytuacji znajduja się imigranci $z$ grupy państw Eurazjatyckiej Unii Gospodarczej, m.in. Kirgistanu, którzy przez władze rosyjskie sa lepiej traktowani i nie sa zobligowani do opuszczenia - w odróżnieniu do innych nacji - terytorium Federacji Rosyjskiej w okresie do trzech miesięcy po utracie zatrudnienia ${ }^{82}$. Tymczasem w samej Moskwie pod koniec kwietnia, pojawiły się informacje, że niemal 10000 migrantów kirgiskich straciło pracę bez otrzymania jakiejkolwiek rekompensaty finansowej ${ }^{83}$.

Nadmienić należy, że rosyjską służbę zdrowia nękają wieloletnie problemy, zaniedbania i chroniczne niedofinansowanie od dekad. Kolejne ekipy sprawujące władzę w ZSRR lekceważyły tę dziedzinę życia społecznego, uznając, że dla rozwoju państwa priorytetem powinno być dbanie o rozwój kompleksu wojskowo-przemysłowego. Taki stan rzeczy utrzymał się także po upadku radzieckiego imperium aż po dzień dzisiejszy, uwzględniając okres rządów Putina. Efekty takiego postępowania to przede wszystkim niedopracowania systemowe i niedobory infrastrukturalne, deficyty sprzętu specjalistycznego w szpita-

79 Koronawirus $w$ Rosji: Główne organizacje biznesu poprosity rzad o wsparcie gospodarki, https://www.gazetaprawna.pl/artykuly/1467629,koronawirus-w-rosji-wsparcie-dlabiznesu.html [dostęp: 30 maja 2020].

80 M.A. Berdy, How Russia's coronavirus crisis... .

81 Iom Central Asia and Russian Federation strategic preparedness and response plan, coronavirus disease 2019, https://www.crisisresponse.iom.int/sites/default/files/appeal/ documents/Central\%20Asia\%20and\%20Russia\%20appeal\%2008.05-FINAL.pdf, February-December 2020, s. 1 [dostęp: 19 czerwca 2020].

82 W. Jaszczyk, P. Pendrakowska, Tydzieñ $w$ Azji: Wielka migracja, czyli Rosja i Azja Centralna $w$ obliczu koronawirusa, https://instytutboyma.org/pl/tydzien-w-azji-wielkamigracja-czyli-rosja-i-azja-centralna-w-obliczu-koronawirusa/ [dostęp: 14 czerwca 2020].

83 Iom Central Asia and Russian Federation strategic..., s. 1. 
lach i mniejszych jednostkach leczniczych oraz niskie wynagrodzenia dla personelu medycznego różnego szczebla. Kryzys koronawirusowy $z$ cała moca powyższe potwierdził. $Z$ początkiem maja 2020 roku dostępność do maseczek i kombinezonów ochronnych w lecznicach pokrywała zaledwie 25-30 proc. zapotrzebowania ${ }^{84}$. Widać wyraźnie, mimo poprawy sytuacji, że opieka zdrowotna w Rosji w dobie pandemii ma poważne trudności, co znacznie utrudnia skuteczna walkę $z$ wirusem. Według Alexandra Gabueva, pracownika Carnegie Moscow Center, rząd rosyjski jest świadomy ewentualności wzrostu liczby infekcji. $Z$ tego też względu władze podejmuja zdecydowane kroki, żeby przeciwdziałać jego nagłemu przyrostowi. Analityk jednocześnie podkreśla, że mimo podejmowanych działań rosyjski system medyczny może nie poradzić sobie $z$ tym problemem ${ }^{85}$. Sytuacji nie poprawia fakt niskiej jakości testów przeprowadzanych na wykrywalność COVID-19, chociaż ich liczba systematycznie rośnie i według wicepremier Tatiany Golikowej, Rosja obecnie znajduje się w czołówce światowej pod tym względem ${ }^{86}$. Kłopotliwe dla rządu w Moskwie staja się natomiast obecne $\mathrm{w}$ przestrzeni internetowej nagrania wypowiedzi rosyjskich lekarzy, z których wynika, że prawdziwe liczby zgonów wywołanych koronawirusem należy liczyć w wielu tysiącach. Medycy akcentuja także problemy związane m.in. z niewystarczająca ilościa sprzętu ochronnego. Najaktywniejszą lekarką obnażająca niniejsze niedogodności jest Anastasia Vasilyeva, szefowa zwiazku zawodowego pracowników medycznych. Oskarża ona władze o fałszowanie statystyk i wzywa społeczność lekarską do przeciwstawienia się publikowaniu nieprawdziwych informacji. Lekarka została aresztowana, gdy próbowała dostarczyć pewne wyposażenie medyczne do szpitali w Nowogrodzie. Według nieoficjalnych informacji, została ona przetransportowana na komisariat policji, gdzie „była duszona i uderzona w brzuch, w wyniku czego zemdlała". Podobno odmawiano jej także dostępu do adwokata ${ }^{87}$. Przypadek ten jednak nie został przedstawiony w oficjalnych mediach, w których to prorzadowi publicyści staraja się prezentować działania władz w jak najlepszym świetle. Niezależnie od nieustajacych komplikacji podczas spotkania $z$ rządem w Moskwie

${ }^{84}$ G. Kuczyński, Nerwy na Kremlu... .

85 R. Standish, Fortress Russia Begins to Show Cracks as Coronavirus Spreads, https:// foreignpolicy.com/2020/03/18/fortress-russia-coronavirus-spread-covid-pandemic/ [dostęp: 9 czerwca 2020].

86 Russia among leaders in coronavirus tests, official says, https://tass.com/society/1144085 [dostęp: 31 maja 2020].

87 D. Jiri, L. Valenta, Putin's Coronavirus Crisis Is Not „Under Control”, https://besacenter.org/perspectives-papers/putin-coronavirus-control/ [dostęp: 9 czerwca 2020]. 
pod koniec marca 2020 roku prezydent Putin stwierdził, że władze powstrzymały masowe rozprzestrzenianie się epidemii. Rosyjski szef państwa powiedział także, że sytuacja jest już ogólnie pod kontrola, pomimo wysokiego poziomu ryzyka ponownej eskalacji choroby ${ }^{88}$. Niezależnie od złożonej deklaracji prezydenta, dopiero 19 maja 2020 roku premier Miszustin zakomunikowal, że wzrost liczby nowych przypadków zakażeń został zatrzymany ${ }^{89}$, co pozwala domniemywać, że wcześniejsze słowa głowy państwa nie były w pełni oparte na faktach. Na początku czerwca rosyjski przywódca podkreślił z kolei, że nie wszystkie problemy zostały rozwiazane, zaś obecnie głównym zadaniem jest zapobieżenie rozwojowi choroby i jej nawrotowi w postaci drugiej fali. Putin jednocześnie zaznaczył, że należy brać pod uwage negatywne scenariusze ${ }^{90}$. Właściwym będzie sformułowanie, że sytuacja ulega pewnej stabilizacji, gdyż Putin zdecydował się w końcówce maja 2020 roku przesunąc na 24 czerwca defiladę $z$ okazji 75 rocznicy zakończenia II wojny światowej, pierwotnie mająca odbyć się 9 maja $^{91}$. Nastroje poprawiła też informacja ministra zdrowia Michaiła Murashko, że Rosja planuje w czerwcu rozpoczać testy kliniczne szczepionki koronawirusowej ${ }^{92}$. $Z$ kolei na poczatku września rząd rosyjski ogłosił, że wyprodukowano szczepionkę Sputnik V, która ma trafić do obiegu cywilnego. Według wspomnianego wyżej szefa resortu zdrowia, w pierwszej kolejności szczepieniu powinny poddać się osoby $z$ grup ryzyka - lekarze i nauczyciele ${ }^{93}$. Pomimo ogłoszonego sukcesu, eksperci wyrażaja daleko idacy sceptycyzm wobec rosyjskiego leku, ponieważ nie przeszedł on trzeciej fazy badań klinicznych. Według wirusologa, Pawła Grzesiowskiego, konieczne sa drobiazgowe badania tego specyfiku i jego skutków ubocznych dla organizmu człowieka ${ }^{94}$. Nie ulega wątpliwości, że Rosja chce pokazać swoje zaangażowanie na

88 R. Standish, Fortress Russia Begins to Show Cracks... .

89 Coronavirus in Russia: The Latest News, https://www.themoscowtimes.com/2020/ 05/19/coronavirus-in-russia-the-latest-news-may-19-a69117 [dostęp: 10 czerwca 2020].

90 К. Аатухина, Голосование - 1 июля, „Российская газета”, nr 117 (8171), 2 июня 2020, s. 1.

91 COVID-19 na terenie Federacji Rosyjskiej, https://www.gov.pl/web/rosja/covid19-na-terenie-federacji-rosyjskiej [dostęp: 15 czerwca 2020].

92 Пандемия коронавируса. Самое актуальное на 30 июня. Подробнее на РБК, https://www.rbc.ru/society/19/05/2020/5e2fe9459a79479d102bada6https://www.rbc. $\mathrm{ru} /$ society/19/05/2020/5e2fe9459a79479d102bada6 [dostęp: 30 czerwca 2020].

93 Rosja wyprodukowała pierwsza partie szczepionki Sputnik $V$ dostepna dla ludności, https: / / wiadomosci.dziennik.pl/swiat/artykuly/7817753,rosja-szczepionka-sputnik-vprodukcja.html [dostęp: 28 września 2020].

94 Rosyjska szczepionka Sputnik V to „ogromne ryzyko”. Naukowcy alarmuja, https:// www.polsatnews.pl/wiadomosc/2020-08-12/rosyjska-szczepionka-to-ogromne-ryzyko -naukowcy-alarmuja/ [dostęp: 27 września 2020]. 
rzecz powstrzymania pandemii i zasugerować międzynarodowej opinii publicznej, że bez Moskwy rozwiązywanie wszelkich problemów natury globalnej jest niemożliwe. Można też przypuszczać, że władze chca za wszelką cenę uspokoić społeczeństwo i utwierdzić je w przeświadczeniu, że sytuacja epidemiczna stabilizuje się, co ma wzmóc poparcie dla Putina wskutek spodziewanej drugiej fali pandemii.

\section{ZAKOŃCZENIE}

Rekapitulując zaprezentowane rozważania, trzeba stwierdzić, że przyszła rola i pozycja Federacji Rosyjskiej na arenie międzynarodowej będzie uwarunkowana konsekwencjami ekonomicznymi i zdrowotnymi szerzacej się obecnie na jej terytorium oraz $\mathrm{w}$ wielu innych miejscach globu pandemii koronawirusa. Za mało prawdopodobny powinniśmy uznać scenariusz, że w najbliższym czasie dojdzie do znacznych zmian na rosyjskiej scenie politycznej. Przedłużenie władzy Putina o kolejne lata na skutek pozytywnego dla niego wyniku referendum $\mathrm{w}$ tej sprawie, pomoże, co prawda, utrzymać względna stabilizację w kraju, lecz na dłuższą metę może także doprowadzić do wystapienia problemów natury społecznej, które moga być dla rosyjskich polityków trudne do powstrzymania.

W obliczu wspomnianych problemów $z$ wyznaczeniem następcy przywódcy spodziewajmy się utrzymania dotychczasowego status quo, co może być jednak podważone w przypadku kolejnych recesji gospodarczych. Mało prawdopodobna jest realizacja zapowiedzi rosyjskich polityków dotyczącej zwiększenia wydatków na służbę zdrowia, gdyż dla obecnej władzy bardziej istotne jest wspieranie dużych przedsiębiorstw oraz instytucji powiązanych bezpośrednio $z$ Kremlem aniżeli kompleksowa pomoc dla wszelkich placówek medycznych i ich pracowników. W dobie narastających komplikacji o różnego rodzaju podłożach, spodziewajmy się intensyfikacji agresywnej polityki Rosji poza jej granicami, w tym stosowania na szeroka skalę metod dezinformacyjnych. Ostatnie protesty w Stanach Zjednoczonych i niektórych krajach europejskich, spowodowane napięciami narodowościowymi oraz ekonomicznymi, stanowia dla Kremla sprzyjające okoliczności do podejmowania prób skłócania ze soba państw europejskich, zwłaszcza południa kontynentu i Bałkanów, które w obliczu niewystarczajacego gospodarczego wsparcia Zachodu w czasie pandemii moga coraz silniej domagać się zniesienia wszelkich nałożonych na Rosję sankcji 
ekonomicznych wprowadzonych po aneksji przez nią Krymu. Ponadto nie można wykluczyć, że część krajów zachodnich, w tym najsilniejsze $z$ nich Niemcy, uznaja, że w celu wypracowania przeciwwagi wobec Chin oraz realizowanego przez Stany Zjednoczone stopniowego wycofywania się ich wojsk z Europy, Rosja powinna stać się krajem, gwarantującym równowagę między oboma supermocarstwami. Dlatego w najbliższym czasie powinniśmy się spodziewać pewnego wzrostu znaczenia Rosji na globalnej arenie, lecz będzie on uwarunkowany także stopniem poradzenia sobie Moskwy z pandemią koronawirusa. 